\title{
Anti-CD3 Antibody
}

National Cancer Institute

\section{Source}

National Cancer Institute. Anti-CD3 Antibody. NCI Thesaurus. Code C118796.

Any antibody that recognizes the CD3 protein complex. 